\title{
A Study on Creating a Successful Classroom Learning Community via Action Research
}

\author{
Juan Wen \\ Department of General Courses, Shanghai Art and Design Academy, Shanghai, China \\ Email: juanwenli@126.com
}

How to cite this paper: Wen, J. (2019) A Study on Creating a Successful Classroom Learning Community via Action Research. Open Journal of Social Sciences, 7, 387-396. https://doi.org/10.4236/jss.2019.710033

Received: October 18, 2019 Accepted: October 28, 2019 Published: October 31, 2019

\begin{abstract}
The studies of students learning together in learning community (LC) programmes have been widely explored. Implementing and evaluating LC programmes challenge teachers considerably. This paper explains how action research was used to design, trial and refine a same-year LC programme to motivate students. The LC programme was successfully integrated into a course of English in 2017 and 2018 about 8 months in span. The paper demonstrates the value of action research for designing the LC programme to increase student motivation. In the meanwhile, the role of transformational teacher leadership and peer leaders played in a successful learning community is elaborated as well. Key elements influencing the success of the programme were: task-based learning activities; appointment of peer leaders; the provision of structured and unstructured student support; teacher assessment and peer assessment; and the use of interactive tutorials. Achieving the appropriate balance of these factors increased students' motivation in their English learning.
\end{abstract}

\section{Keywords}

Action Research, Teacher Leadership, Learning Community

\section{Introduction}

In the past few years there has been a gathering interest in the concept of teacher leadership and learning community, as teacher leadership exerts a great influence on the effective learning of the students. Helterbran (2010) explains that, "teacher leadership rises from within the teaching ranks and expresses itself in a myriad of ways for the betterment of students, specifically, and school in general." [1]. According to Lambert (2000), "teacher leadership is an enrichment of the teaching profession. Teachers may help to lead the school even in a capacity 
other than Principal or Vice Principal" [2].

Creating a learning community in a school is a critical factor for teachers' professional development and enhancing student learning as part of curriculum reforms (Verbiest et al., 2005) [3]. A professional learning community could enhance the professional competence of teachers and help to create the pedagogical content knowledge necessary to implement the new curriculum for effective student learning (Cheng, 2009; Hord, 1997) [4].

\section{Literature Review}

\subsection{Learning Community}

The theoretical framework for the learning community was derived from social constructivist philosophy. McKinley (2015) claims that social constructivism maintains that human development is socially situated and knowledge is constructed through interaction with others [5]. Another term similar to it is Social Constructionism, which should be distinguished from Social Constructivism. Social constructionism is a theory of knowledge in sociology and communication theory that examines the development of jointly constructed understandings of the world that form the basis for shared assumptions about reality. The theory centers on the notions that human beings rationalize their experience by creating models of the social world and share and reify these models through language.

Within higher education, learning communities provide organized learning support with the overall goal of enhancing the academic experience and improving academic performance. Schools may use a learning community to introduce incoming students to the expectations of university life and to serve as a social support structure as students transition from high school to college. Learning communities socialize students to the expectations of a certain program of study as a result of exposure to upper classmates and increased interactions with faculty members. The structure and function of learning communities can be complex, the most complex being intensely coordinated programs that incorporate faculty members, student mentors, and prescribed activities linked to an entire curriculum. An informal group of students working together as they study are also considered to be learning. Despite varying structures, outcomes have been positive with improvements seen in student retention, student achievement, and student progress.

Vocational education, as a newly-born part of Chinese education in the Mainland China context is equivalent to UNESCO's term technical and vocational education (Zhao and Lu 2007) [6], with, in China, specialized senior secondary schools, technical workers schools, and vocational senior secondary schools. The nature of vocational colleges is required to lay emphasis on professional skills ignoring general courses like English, maths and PE. The literature on English teaching approaches in the context of Chinese vocational colleges is scarce. Learning Community has been proven to be an effective medium to en- 
hance the overall performance of classes such as improved learning efficiency, motivated students. This study is trying to find out its feasibility in Chinese vocational colleges, more specifically, in my college.

\subsection{Teacher Leadship}

Leadership is a process whereby an individual influences a group of individuals to achieve a common goal (Northouse, 2013) [7]. Teacher leadership always fascinates a great variety of researchers, nevertheless, they have not arrived at consensus of its definition. The earliest model focused on teacher leaders as efficient managers (Evans, 1996) [8]. Leithwood and Jantzi's studies (1999, 2000) [9] also took managing classroom conditions to be an aspect of leadership. The second model focuses on teachers as instructional guides. Afterwards, York-Barr \& Duke (2004) [10] came to a conclusion that there are different opinions of what teacher leadership consists of. Those various definitions are fundamentally categorized based on what teacher leaders do in their schools.

From the perspective of the role played by teachers, there are a great variety of statements. Childs-Bowen et al. (2000) maintained that when teachers play a significant role in academic institution in influencing student learning, contributing to school improvement, inspiring excellence in practice, as well as empowering stakeholders to participate in educational progress, they exert teacher leadership. Similarly, Crowther et al. (2002) held that teacher leadership advances school success by the way that teacher leaders transform teaching and learning and link the school and community together, and give an impetus to the community's social mission and quality of life. Teacher leadership played a key role in leading the progress of not only to the class but also to the school, therefore it contributed directly to improve students' achievement (Tang \& See, 2009) [11]. Based on the literature review, developing teacher leadership could bring a positive impact on classroom management. Previous studies like Hickey and Harris (2005) [12], Khalid (2007) [13], Siti Aida (2011) [14], and Tan (2011) [15] have indicated that the practice of teacher leadership would improve classroom management skills of teachers and student performance as well. Teacher leadership assists school development at different levels. At the student level, the ultimate goal of teacher leadership is to better student learning, which is to be achieved through the constant improvement of teaching and learning practices to support learners to develop their autonomy and freedom in their learning.

With regard to the categories of leadership, in my situation, I put myself in transformational leadership. Transformational leadership comes up to the surface when a leader encourages followers with a shared vision, motivates them to achieve the vision, and offers them the prerequisite resource for reaching their highest potential. Acting as role models and mobilize commitment, transformational leaders support optimism and try as they may to satisfy the followers' needs for growth (Bass, 1996; Bass \& Avolio, 1998) [16]. Specifically speaking, a leader (teacher) displaying transformational leadership style influence the followers (students) in four major ways: 1) Idealized Influence: It involves the 
strong vision and mission determination of a transformational leader who is a role model for the followers and whose behaviours are identified with the followers. 2) Inspirational Motivation: It is transformational leaders who define original ideas and encourage entrepreneurship. They induce a change to the organization by creating an enthusiastic team spirit and motivate their followers along the way. 3) Intellectual Stimulation: Transformational leaders motivate their followers to be innovative and challenging by encouraging their followers to discover ideas of their own and produce creative solutions to problems. 4) Individualised Consideration: Of the four ways, the thought of individualised consideration, (yin cai shi jiao), the Chinese equivalent, was held by Confucius, a great Chinese philosopher and educator as well.

\section{Implementing the Research}

\subsection{The Aim of the Paper}

The specific aims of this paper are to:

1) Demonstrate the use of action research to motivate my students in a successful learning community;

2) Identify the combination of strategies that helped to improve student performance in a LC programme in a two-term English course over three cycles;

3) Describe the interplay of factors affecting student motivation and academic performance; and

4) Use action research to contribute to the scholarship of teaching and learning;

5) Identify the role of teacher leadership in creating a successful learning community;

6) Find the implications in a similar professional context.

\subsection{Implementing Action Research}

Image 1 illustrates the four action research phases used in the three cycles to improve the LC programme. In each cycle the phases progressed as the above.

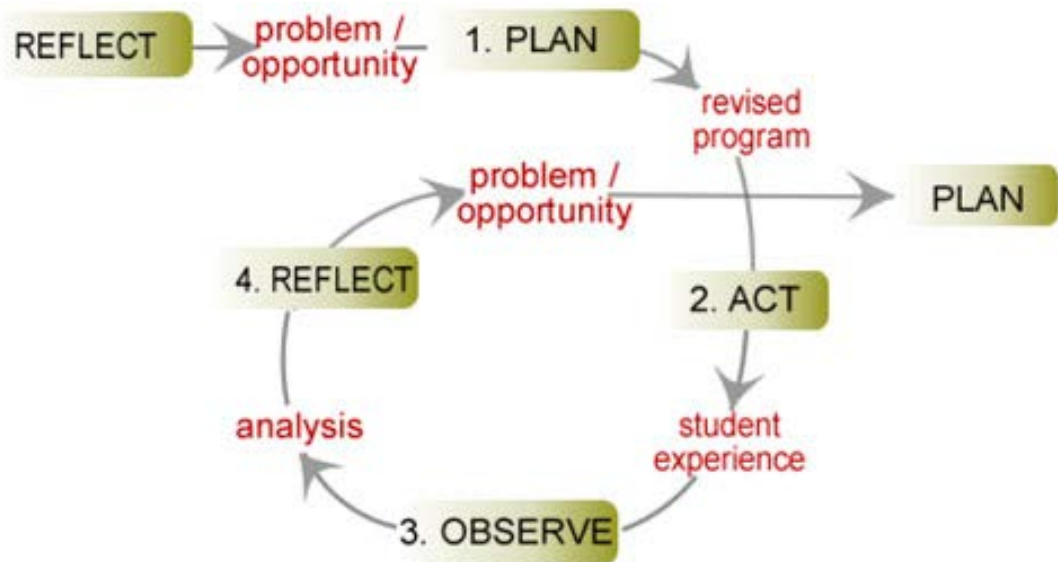

Image 1. Four phrases of action research. 
Educational Action Research:

1) Plan: improvements were planned.

2) Act: improvements were implemented.

3) Observe: observation data were collected, analysed and interpreted.

4) Reflect: problems and opportunities for improvement were found.

\section{The three cycles}

Cycle one: The Middle Term of 2017: Task-based teaching activities were introduced through learning communities.

Act

The students (enrolled in 2017) majoring in product design participated in the Learning Community Programme. There are 32 students in this class. The 32 students were subdivided into 8 learning communities with 4 students in each team.

Table 1: Data from the student questionnaire for 2017, 2018: percentage of students who agreed or strongly agreed with each statement.

Table 2: The following figure indicates the overall satisfaction from the students on their subject of English (Middle term of 2017, final term of 2017 and middle term of 2018)

The positive response from the questionnaire included: agreement that LC is interesting (Item 1, 63\%); motivating the students in English learning(Item 2, 54\%); willingness to attend English class(Item 3, 67\%); gaining more confidence in English learning (Item 5, 58\%). They got more help via learning communities. Negative responses included lack of a peer leader to act as a leader to coordinate the whole task-solving progress.

In Table 2, in the middle term of 2017, the overall satisfaction of the English subject from the students was $50 \%$.

\section{Reflect}

It was decided that a peer leader was needed to help his/her teammates settle on priorities and assign them different tasks to motive the students more.

\section{Cycle Two}

Plan Select a peer leader based on various elements including his/her devotion, language competency and leadership skills for each group. Give tutorials to each peer leader collectively and individually. Employ teacher assessment on their learning tasks of each learning community.

\section{Act}

A peer leader was chosen for each group, who was responsible for the coordination of his/her teammates in completing their learning tasks. A tutorial was given to them every two weeks by me, in which they raised questions they met and discussed with other peer leaders to come up with solutions.

\section{Observe}

The end-of-semester student questionnaire (Table 1) indicated a statistically significant increase in the overall student experience of the learning community with a peer leader (Items 10 - 18) compared with Cycle One. The response rate for the standard school course evaluations was $75 \%$. Overall satisfaction 
Table 1. Questionnaire on the roles of learning community.

\begin{tabular}{|c|c|c|c|}
\hline Year & $2017 \mathrm{MT}$ & $2018 \mathrm{FT}$ & $2018 \mathrm{MT}$ \\
\hline Class numbers & 32 & 32 & 32 \\
\hline Response rates & $75 \%$ & $75 \%$ & $81 \%$ \\
\hline \multicolumn{4}{|c|}{ Benefits from learning community (LC) programme } \\
\hline The LC programme was interesting. & $63 \%$ & $75 \%$ & $77 \%$ \\
\hline The LC programme motivated me to learn more. & $54 \%$ & $79 \%$ & $73 \%$ \\
\hline $\begin{array}{l}\text { The LC programme made me } \\
\text { willing to attend the English classes. }\end{array}$ & $67 \%$ & $83 \%$ & $88 \%$ \\
\hline $\begin{array}{l}\text { My role in completing my tasks and my shared tasks, both } \\
\text { my English language skills and peer interactions improved. }\end{array}$ & $67 \%$ & $87.5 \%$ & $85 \%$ \\
\hline $\begin{array}{l}\text { I built up my confidence because I solved the } \\
\text { problems I had never done before on my own. }\end{array}$ & $58 \%$ & $71 \%$ & $88 \%$ \\
\hline $\begin{array}{l}\text { I was more team-spirited than before because I had to } \\
\text { cooperate with my teammates to finish the complex tasks. }\end{array}$ & $71 \%$ & $83 \%$ & $77 \%$ \\
\hline $\begin{array}{l}\text { When I was working in a LC group, I appreciated the } \\
\text { benefits of teamwork to carry out complex tasks. }\end{array}$ & $63 \%$ & $75 \%$ & $73 \%$ \\
\hline $\begin{array}{l}\text { When I was working in a LC, I learned faster about } \\
\text { English language skills than if I had simply studied on my own. }\end{array}$ & $63 \%$ & $75 \%$ & $88 \%$ \\
\hline $\begin{array}{l}\text { I learned a lot about speech from my teammates } \\
\text { in my LC when they made their presentations. }\end{array}$ & $58 \%$ & $75 \%$ & $77 \%$ \\
\hline \multicolumn{4}{|l|}{ Myrole as a member of the LC group } \\
\hline $\begin{array}{l}\text { As a result of co-study in } \mathrm{LC} \text {, } \\
\text { I got more help from my teammates. }\end{array}$ & $67 \%$ & $79 \%$ & $88 \%$ \\
\hline $\begin{array}{l}\text { While I worked as captain, I was encouraged to exert } \\
\text { the influence of my leadership to motivate my teammates. }\end{array}$ & NA & $87.5 \%$ & $88 \%$ \\
\hline While I served as a learner, I was motivated to learn more. & $67 \%$ & $92 \%$ & $92 \%$ \\
\hline $\begin{array}{l}\text { We worked more efficiently with a peer leader } \\
\text { because he/she worked as a coordinator in } \\
\text { our group and helped us defining our priorities. }\end{array}$ & NA & $83 \%$ & $88 \%$ \\
\hline \multicolumn{4}{|c|}{ The role of both peer assessment and teacher assessment } \\
\hline $\begin{array}{c}\text { As a result of performing teacher assessment on } \\
\text { learning activities of the LC, I felt a great sense of } \\
\text { participation for it was a part of my final-term performance. }\end{array}$ & NA & $75 \%$ & $96 \%$ \\
\hline $\begin{array}{l}\text { In performing peer assessment I listened } \\
\text { more attentively to my peers' LC presentation. }\end{array}$ & NA & $79 \%$ & $85 \%$ \\
\hline I enjoyed performing peer assessment of the LC presentations. & NA & $96 \%$ & $77 \%$ \\
\hline $\begin{array}{l}\text { I preferred teacher assessment based on } \\
\text { our tasks for it was a small part of my final-term assessment. }\end{array}$ & NA & $83 \%$ & $88 \%$ \\
\hline $\begin{array}{l}\text { I came to realise my problems when my teacher } \\
\text { pointed out my mistakes occurring constantly in my learning. }\end{array}$ & $67 \%$ & $79 \%$ & $85 \%$ \\
\hline $\begin{array}{l}\text { Knowing my peers would be assessing my group's presentation made } \\
\text { me more responsible in contributing to the small group. }\end{array}$ & NA & $83 \%$ & $92 \%$ \\
\hline $\begin{array}{l}\text { I think performing peer assessment of the LC presentation was } \\
\text { valuable to my improvement of language skills. }\end{array}$ & NA & $83 \%$ & $88 \%$ \\
\hline
\end{tabular}

Notes: NA, not available, MT, Mid-term, FT, Final-term. 
Table 2. Overall satisfaction from students.

\begin{tabular}{cccc}
\hline Year & $2017 \mathrm{MT}$ & $2017 \mathrm{FT}$ & $2018 \mathrm{MT}$ \\
\hline General satisfaction & $50 \%$ & $72 \%$ & $81 \%$ \\
\hline
\end{tabular}

increased to $72 \%$ in this cycle (Table 2). Staff observed that students in each group with a peer leader as a coordinator worked more efficiently when attacking their task-based problems.

\section{Reflect}

Students' positive experience of LC programme suggested that working with a peer leader and teacher assessment as well could motivate students more in their learning activities. In the following cycle, the role of peer assessment in motivating learners was tested.

\section{Cycle Three: middle term of 2018}

\section{Plan}

Change the LC learning task from a task-solving activity by each group to an interactive tutorial. Increase structured and unstructured support for the more complex task of preparing and offering topic-based tutorials. Incorporate peer assessment of the small LC group work by individual members of the group.

\section{Act}

Each LC group selected one of 6 units on which to base an interactive tutorial for the class. Structured course support via briefing and debriefing sessions with each LC group was offered by me, and unstructured support via informal consultations.

Observe

Cycle Three saw an overall increase in the percentage of each Item. Compared with the middle term of 2017 and the final term of 2017, the response rate was $81 \%$ and overall satisfaction increased from $72 \%$ to $81 \%$ (Table 2).

\section{Reflect}

Our experience in developing and refining this programme indicates the importance, having a peer leader in each learning community, teacher assessment and peer assessment for the full motivation of students in LC.

\section{Conclusions and Implications}

\subsection{Use of Action Research to Contribute to the Scholarship of Teaching and Learning}

While some of the changes we introduced in each cycle have previously been described, the combination of elements that we introduced, and their cumulative effect on students' experience of learning, contribute to exploration of how to implement LC effectively. Communicating our experience, so others may build on the knowledge generated through these action research cycles, illustrates the potential of the scholarship of teaching and learning to extend inquiry beyond the local context. For example, further exploration of the use of tutorials for contextualising students' learning, and increasing both creativity and interactiv- 
ity, would help to determine the applicability of the approach across other disciplines. Similarly, further investigation would determine whether comparable results would occur with students not undertaking a highly structured vocational course with preestablished student relationships. While having a peer leader, the inclusion of structured and unstructured student support, teacher assessment and peer assessment and specific requirements regarding interactivity may be generally important for LC programmes to improve student motivation, the way these elements are designed will be dependent on contextual factors. Participation in the scholarship of teaching and learning offers the opportunity for continuing development of a "checklist" of potentially important factors for well-structured, assessable LC programmes.

\subsection{The Role of Teacher Leadership in Creating a Successful Learning Community in Classroom}

In my case, a learning community is a group of students who share common academic goals and attitudes, who meet regularly to collaborate on classwork with the guidance of a teacher. A successful learning community in my situation has the following features: first, it is structured in form. Second, the learners share a common goal. Third, in the community, all learners are willing to be engaged in learning activities. Fourth, they attack the problems via cooperation and discussion with each other. The role of teacher leadership in creating a successful learning community could be indicated in the following aspects: first, teachers, as an instructor and leader initiate the programme of creating a learning community. Without my initiation of launching such a programme, all the work afterwards would have been impossible. Second, teachers serve as inspirations, which motivate learners to make more efforts. In my professional context, my students tend to give up when they are confronted with difficulties. In such a situation, my encouragement and instructions count considerably. Sure enough, their improvement is also inspiring to me. Third, teachers work as supervisors monitoring all the learning activities concerned. Once there is something off the track, the teachers are required to make adjustments accordingly. Without my severe supervision, my students could have been less industrious and their learning progress may not have undergone efficiently. So the supervision is a must to my research action and assures that the whole study went smoothly. Last but not the least, teachers act as role models with peer leaders to follow suit. In my teaching practice, both peer leaders and I cooperated with each other to draw the attention of the other team members so that we could accomplish our shared assignments.

\subsection{Implications}

My study witnessed increasing motivation of my students. My model, in some sense, provides pragmatic guidelines for school teacher, especially Chinese vocational school teachers to create a learning community in their own classes. Teachers must have a personal vision of how leadership will be provided for the 
class before working with their colleagues and students to develop a shared vision for the entire participants. They should share their own vision with their colleague and students, be assessed on their commitment to the vision and be sufficiently open-minded to accept the welcome differing opinions. Teachers should be committed to their leadership role as agents of change, because any changes in a class must be accepted, appreciated and nurtured by themselves.

In addition, school leaders are expected to support such programmes and offer financial assistance. What is more, school leaders are required to cultivate a good environment, and foster a collaborative culture and trust among his/her faculties, in which teachers and students thrive to make changes in their school by collaborative efforts and shared vision. Next, school leaders are supposed to empower their teachers to make changes in their school. They could publicise the successful teaching programme school wide to inspire other teachers to follow. By doing so, both the school and individual professional development of teachers could be strengthened. Finally, school leaders could formulate policies for professional development via creating learning communities for teachers. It would be desirable if teacher participation in profession-related Learning Study training activities could be stated in the school's annual plan as an essential feature fully supported by the school authority. They should also create a school structure and routines that support a learning community and encourage regular professional interaction in the face of systemic problems and school resistance to collective learning.

\section{Conflicts of Interest}

The author declares no conflicts of interest regarding the publication of this paper.

\section{References}

[1] Helterbran, V.R. (2010) Teacher Leadership: Overcoming "I Am Just a Teacher' Syndrome". Education, 131, 363-371.

[2] Lambert, L. (2000) Building Leadership Capacity in Schools. APC Monographs.

[3] Verbiest, E., Ansems, E., Bakx, A., Grootswagers, A., Heijmen-Versteegen, L, Jongen, T., et al. (2005) Collective Learning in Schools Described: Building Collective Learning Capacity. The ICSEI Conference, Barcelona, Spain.

[4] Cheng, C.K. (2009) Cultivating Communities of Practice via Learning Study for Enhancing Teacher Learning. KEDI Journal of Educational Policy, 6, 81-104.

[5] McKinley, J. (2015) Critical Argument and Writer Identity: Social Constructivism as a Theoretical Framework for EFL Academic Writing. https://doi.org/10.1080/15427587.2015.1060558

[6] Zhao, Z.Q. and Lu, L.W. (2007) China's TVET Teachers and Their Professionalization. In: Grollmann, P. and Rauner, F., Eds., International Perspectives on Teachers and Lecturers in Technical and Vocational Education, Vol. 7, Springer, Dordrecht, 55-76. https://doi.org/10.1007/978-1-4020-5704-5 3

[7] Northouse, P.G. (2013) Leadership: Theory and Practice. 6th Edition, Sage, Thousand Oaks, CA. 
[8] Evans, R. (1996) The Human Side of School Change. Jossey Bass, San Francisco, CA.

[9] Leithwood, K. and Jantzi, D. (2000) Principals and Teacher Leadership Effects: A Replication. School Leadership and Management, 20, 415-434. https://doi.org/10.1080/713696963

[10] York-Barr, J. and Duke, K. (2004) What Do We Know about Teacher Leadership? Findings from Two Decades of Scholarship. Review of Educational Research, 74, 255-316. https://doi.org/10.3102/00346543074003255

[11] Tang, K.N. and See, C.M. (2009) Special Education Teacher Leadership Practice: A Malaysian Study. The International Journal of the Humanities, 7, 1-15.

[12] Hickey, W.D. and Harris, S. (2005) Improved Professional Development through Leadership. The Rural Educator.

[13] Khalid, M. (2007) Least Common Multiple of Teacher Leadership Styles: Implication for Classroom. Bulletin of Education and Research, 29, 19-42.

[14] Siti Aida, I. (2011) Teacher Leadership in Improving the Quality of Teaching in a National Secondary School in Shah Alam. Unpublished Master Thesis, Universiti Malaya, Kuala Lumpur.

[15] Tan, S.H. (2011) Teacher Leadership at an Elementary School in the District of Petaling Utama, Selangor. Unpublished Master Thesis, Universiti Malaya, Kuala Lumpur.

[16] Bass, B.M. and Avolio, B.J. (1998) Transformational Leadership, Charisma, and beyond. In: Hunt, J.G., Baliga, B.R., Dachler, H.P. and Schriesheim, C.A., Eds., Emerging Leadership Vistas, Lexington Books, Lexington, MA, 29-49. 